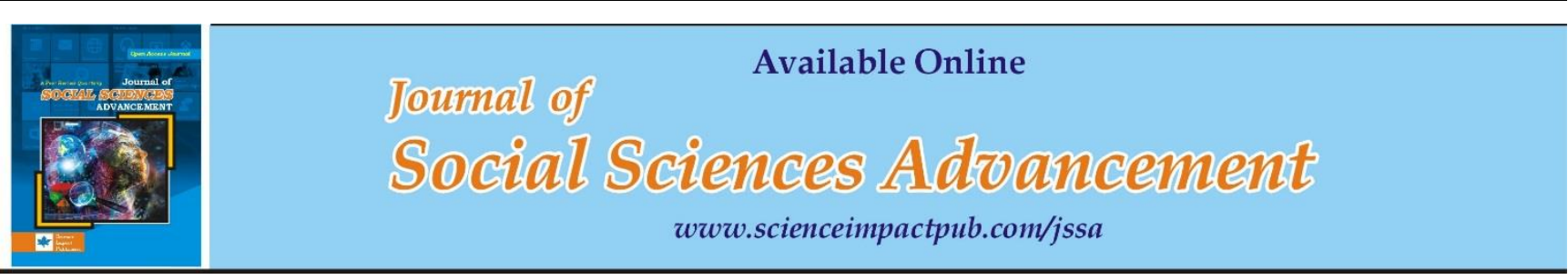

\title{
Design of Gender-Specific Benefits in Social Security Schemes: Experience from Tanzania
}

\author{
Mathias Mkude ${ }^{1}$ and Gertrude Zacharia ${ }^{2}$ \\ 1Department of Gender Studies, Tengeru Institute of Community Development, Arusha, Tanzania \\ 2International Labour Organization, Dar es Salaam, Tanzania
}

\begin{abstract}
This study aimed to investigate designing and challenges of the implementing gender-specific benefits in social security schemes i.e., National Social Security Fund (NSSF) and Public Service Social Security Fund (PSSSF) in Dar es Salaam, Tanzania. Twenty-four (24) respondents were involved in this study. Face-to-face Semi-structured interviews were the main method used in data collection. Data collected were analyzed through Thematic and Content analysis. The findings revealed that the Maternity benefit is the only gender-sensitive benefit included in social security schemes. Additionally, the findings revealed that policies, programs, strategies, and laws concerning social protection are gender blind while social security benefits are characterized by the exclusion of paternity benefits and informal sectors. The study concludes that gender-centered social security benefits can be viewed in the design and implementation of social security benefits. The study recommends that the government should reform social security policies to suit gender as a primary factor in its design. The study recommends that members should demand changes in benefits because members' contribution is a great source of income in social security schemes.
\end{abstract}

\begin{tabular}{l}
\hline Keywords: Social security schemes; Social security; PSSSF; NSSF; Gender-specific benefits \\
\hline${ }^{*}$ Corresponding Author: Mathias Mkude, Email: matimkude@gmail.com \\
(C) The Author(s) 2021.
\end{tabular}

\section{INTRODUCTION}

The promotion of gender equality in the design and implementation of social security schemes is very crucial to the attainment of a just society. However, there has been significant concern from feminists about gender equality and social security schemes over the past decade (Ulrichs, 2016). The interest of the feminist is mainly informed by looking at ways in which social policies promote equality and wellbeing for all (Piovani \& Avsar, 2015). Social security can play a significant role in women's economic empowerment and greater gender equality when designed, implemented, and monitored in a gender-responsive way (Tessier et al., 2013). Contrary, the neglect of gender in designing and implementation of social policies, produces unequal social and economic outcomes for both men and women, and significant challenges persist. This study focused on how gender-specific social security benefits are designed and implemented. Between 71\% percent of the world population, the majority being women lack comprehensive social security coverage, and 55\% are completely not covered by any social security (ILO, 2019).

Coverage gaps for women of working age remain high (Holmes et al., 2019). For the industrialized countries in Europe, gender equality in social security gained momentum in the 1990s when the adult workers model took place (Sinem, 2019). The model promotes the role of individual agency for both women and men because of the steady increase in female labor force participation rates in many industrialized countries (Lewis, 2001). However, the gender gap in earning remains throughout Europe (Daly, 2001). In most developing countries such as Sub Saharan Africa and parts of Asia and Pacific, the burden for women furthered by over-representation in part-time employment where insufficient attention has remained in the design and implementation of social protection policies and programs (Matteazzi et al., 2017; Holmes et al., 2019).

In a country like Tanzania, the coverage of social security schemes is minimal, covering a small population - mainly civil servants and formal sector workers (Ulrichs, 2016). Gender disparities in Tanzania's social security schemes are evident in formal sector employment, where men account for $71 \%$ of workers (Lokina et al., 2016). Social security schemes in Tanzania exclude the majority of informal workers, including a disproportionate number of women with $69 \%$ of them working in agriculture (Holmes \& Scott, 2016). Furthermore, in Tanzania, being in the formal sector is a legal requirement for anyone to be a member of the social security scheme (Ulandssekretariatet, 2018). Therefore, the increasing number of women in paid employment in Tanzania is a significant factor in gender equality promotion (Lokina et al., 2016). However, the labour market is characterized by an increasing number of women in the informal 
sector. The labour market structure is sex-segregated in the sense that the share of men in a senior and middle position is higher by $82.6 \%$ compared to that of women which is $17.4 \%$ (NBS, 2014).

The prevailing cultural and social norms remain a principal cause for excessively disadvantaging women and generating numerous restrictions for them in social security accessibility (Myamba, F., \& Kaniki, S. 2016). Women also have limited access to income and decision-making over expenditures (Piovani \& Avsar, 2015). Moreover, the majority of women are constrained from access to the labor market; experiencing high levels of illiteracy and numeracy incapability (Lokina et al., 2016). Social security schemes in Tanzania provide unequal benefits between men and women covered. PSSSF and NSSF are among Mandatory social security institutions operating in Tanzania (Ulandssekretariatet, 2018). The Act of Parliament No. 28 of 1997 established NSSF to replace the National Provident Fund (NPF) and serve private employees (Mhando \& Kayuni, 2019).

On the other hand, PSSSF was established by the Act of Parliament No. 2 of 2018 to cater to the social security needs of employees in public service. The Act also repeals the Public Service Retirement Benefits Act, the LAPF Pensions Fund Act, the GEPF Retirement Benefits Fund Act, and the PPF Pensions Fund Act (Ulandssekretariatet, 2018). The two schemes (PSSSF and NSSF) recruited 15000 members from 2010 to 2016. However, the overall coverage of social security in Tanzania is less than $1 \%$ of the entire population, whereas only $6.5 \%$ of the formal working population is covered (Ahmed \& Ndyali, 2018). Fragmentation between the formal sector and the dominance of the informal sector in Tanzania contributes to the low coverage of the social security schemes (Rwegoshora, 2016 \& Masanyiwa, et al., 2020). Apart from the contextual environment, constraining the rights of women's participation in the social security schemes for instance women working in the informal sector and limitation to the labour market, the increased number of women in the formal sector experience unequal benefits in social security schemes (Piovani \& Avsar, 2015). Therefore, it was of interest to investigate how gender equality is enhanced in the design of social security benefits in Tanzania.

\section{METHODOLOGY}

\section{Research Design}

This study is broadly situated in the interpretive paradigm. It was qualitative where in-depth semi-structured interviews were used to solicit data. The reason for choosing qualitative research in this study was to gain a rich and detailed understanding of gender equality based on first-hand lived experiences. Data in this qualitative research were concerned with the depth of the knowledge and experiences as opposed to quantity.

\section{The Sample}

Twenty-four key respondents of which 5 were from social security schemes and 19 were from sectors benefiting from social security schemes were involved in this study. The sample was selected through purposive sampling as they possessed information and experience about distribution and access to social security benefits (Morse, 2010). The selection of the sample was done in Dar Es Salaam because the active labor force is 1.9 million, compared to 5.1 million from the rest of the urban areas in Tanzania (URT, 2014). On the other hand, Dar es Salaam comprises $28 \%$ of informal sector employment as well as one-third of the non-farming activities taking place in urban areas of the country (Adams et al. 2013).

\section{Ethical Consideration}

All participants were subjected to informed consent before they participated in the study. All participants were free to give or not give their thoughts in every question asked. Participants were allowed to be free to leave the conversation if they found the conversation was not giving them conformability. The anonymity and confidentiality of the information given were assured and the names of participants have not appeared on the final report.

\section{Data collection and analysis}

Researchers started data collection by visiting NSSF and PSSSF offices in Dar es Salaam as the main social security scheme of the country after merging the social security funds (Mbashiru \& Domasa, 2018), which provides social security benefits. Staffs were from NSSF and PSSSF while members' experiences were collected from the five organizations visited which were Mwalimu Nyerere Memorial Academy (MNMA), Trade Union of Industrial, Commercial, Finance, Service and Consultancy Workers (TUICO), Alaf Limited Tanzania, Tanzania Portland Cement Public Limited Company (TPC PLC), and Bora Industries Ltd to gather social security benefit's experiences from both NSSF and PSSSF members. Qualitative data obtained were subjected to thematic content analysis. Through Thematic analysis, a researcher went through six stages to analyze the collected data. It involved the data familiarisation through transcription, reading, and rereading of data as well as noting down initial ideas. Then researchers generated initial codes in twenty-six (26) codes. Latter on researchers searched for the sub-themes, in which nine (9) subthemes were identified. Finally, researchers came up with four (4) themes which were hierarchically presented. 


\title{
RESULTS OF THE STUDY
}

\section{The Design of Gender-specific benefits}

The design of gender-specific benefits in the social security schemes is characterized by the inclusion of maternity benefits but excludes paternity and women in the informal sector. Moreover, the design is gender blind in the criteria for design social security benefits, and social security policies, laws, strategies, and programs.

\section{Inclusion of Maternity Benefits in Social Security Benefits}

The inclusion of maternity benefits in social security benefits refers to the situation in which maternity benefit is included as one of the seven benefits provided by NSSF and PSSSF. Other benefits are Retirement, Death gratuity, Invalidity, survivorship, Sickness, unemployment. The findings of the study revealed that the inclusion of maternity benefit as one among the benefits in the social security schemes gives confidence to women who are members of the social security schemes during postnatal care. The cash benefits help to address heal issues and provide comfortability to a mother and a child or children.
"Of course, a maternity cash benefit is beneficial to me and helpful to the whole family, especially if my husband has a good relationship with me. Therefore he will benefit from the money earned as maternity cash benefit because I will take that money home" (TPC PLC respondent.)

Moreover, through documentary review, the findings revealed that the inclusion of maternity benefits in the design of policies and programs is useful.

\begin{abstract}
"Maternity protection is a key component of the transformative policies called for in the 2030 Agenda for Sustainable Development and is essential to the achievement of multiple Sustainable Development Goals, including Goals 1, 2, 3, 4, 5, 8, and 10" (ILO, 2017).
\end{abstract}

\section{Gender Blindness in the Criteria for Design Social Security Benefits}

Gender blindness in the criteria for design social security benefits refers to the inconsideration of a gender lens in the design of social security benefits. The findings of this study showed that gender is nowhere in all criteria for design social security benefits. The criteria used in the design of social security are informed by research and ILO nine contingencies.

\begin{abstract}
"When you look at the benefits we offer, you realize that almost all of them were developed from ILO convention No. 102, which addresses contingencies which people need to be protected against, they are nine in total. NSSF provides seven out of those nine. The design depends on the NSSF law and international guidelines mostly provided by ILO" (NSSF Staff).
\end{abstract}

\section{Gender blindness in Social Security Policies, Programs, Strategies and Laws}

Gender blindness in the policy regards the non-inclusion of gender aspects in the design of social policies. The findings of this study revealed that gender aspects are not in the core criteria for the design of social security policies in Tanzania. The focus of the policy is highly influenced by the three-tier system as promoted by ILO.

\begin{abstract}
"The design of social security benefits does not put into account gender issues, instead the design of benefits is informed by research and ILO minimum standards. Gender is not one of the direct criteria. But through the benefits, we offer also men and women fall under the same formula (NSSF Staff)
\end{abstract}

\section{Exclusion of Paternity benefit and Women in the Informal Sector}

The exclusion of paternity and women in the informal sector refers to the inability and ineligibility of fathers or husbands working in the formal sector and other people working in the informal sector to access gender-specific specifically from social security schemes. The findings of the study revealed that despite maternity benefits being the crucial benefits in the social security schemes, it only suits women need who is members of the social security schemes when giving birth, while there are no specific benefits that suit only men who are members of the social security schemes. The informal sector workers lack regular income, and therefore the schemes cannot collect contributions monthly.

\begin{abstract}
We have maternity benefits but not paternity ones. The maternity benefits also help men because it reduces the burden to both parents...... But for the women who are not members, cannot have access to all benefits. The benefits need to be collected from employer and employee, this includes penalties to employees. Therefore to be a member you must have a formal contract that explains the duration of work but the distribution of your salary and what your employer is supporting you (PSSSF Staff).
\end{abstract}

\section{DISCUSSION OF THE FINDINGS}

The findings of this study revealed that gender is not primary a factor in the design of social security schemes in Tanzania. The findings of this study resonate with studies conducted by different authors in different countries (Li, 
Feng, \& Gizelis, 2008; Rwegoshora, 2016 \& Anifalaje 2017). However, in some countries like Switzerland, the design of social security schemes give considerable attention to gender as a primary factor in promoting gender equality in social security schemes (Fagan \& Rubery, 2018). Working in the formal sector is the basic prerequisite for an individual to access benefits from social security schemes (Ulandssekretariatet, 2018), and therefore the majority of women are left out of social security schemes because they operate in the informal sector (Rwegoshora, 2016).

Although study findings show that paternity benefit does not exist as maternity benefit in social security schemes in Tanzania, Rwegoshora, (2016) argues that the design of Tanzania social security benefits has centered on a male breadwinner model. In Tanzania, 71\% of the formal jobs are occupied by men compared to women counterparts (Lokina et al., 2016). Therefore the majority of men are enjoying more of the long-term social security benefits compared to women. The existence of imbalances in the access to social security benefits between men and women promotes gender inequality in social security schemes (Cameron 2019) as pictured by the findings of this study. On the other hand, Halvorsen \&Perdersen (2019), consider the design of gender-specific benefits as a solution to gender inequality in the social protection policy, some things which do not exist in Tanzania as study findings show.

The findings of this study revealed that the design social security schemes in Tanzania provide maternity benefits to women belong to the formal sector. The findings are similar to the study conducted by Anifalaje (2017) in Nigeria, where only women employed in the formal sector have access to maternity benefits as part of the contributory benefits. On the other hand, the findings of this study show that the design of the social security scheme in Tanzania is different from that of India because in India maternity benefits of at least Rs. 6,000 per child are a legal right of all women (Dreze, Khera, \& Somanchi, 2021). Similarly, the findings of this study revealed that the design of maternity benefits in Tanzania has historically divided women workers by focusing on occupation and labor market positions while at the same time small efforts have been given to women in the informal sector.

\section{CONCLUSION AND RECOMMENDATIONS}

\section{Conclusion}

The study concludes that the consideration of gender equality in social security schemes could be viewed in the design and the implementation of gender-specific benefits. The design of gender-specific social security benefits includes only maternity benefits for women working in the formal sectors. Men working in both formal and informal sectors as well as women from the informal sectors are denied paternity and maternity benefits. Policies, programs, strategies, and laws concerning social protection are gender blind.

\section{Recommendation}

i. The government should reform social security policies to suit gender as a primary factor in its design. The inclusion of gender aspects in the design of social security schemes will open discussion about gender-specific benefits and hence the improvement of the social security benefits. The reform of the social security policy suiting gender-specific benefits needs to be participatory.

ii. Members need to demand changes in the social security schemes. Given their power based on contribution, social security members need to appeal not only for the improvement of the benefit packages but also the introduction of new gender-specific benefits such as paternity benefits. The demand from members can easily be given attention, as they are contributors to the schemes.

\section{REFERENCES}

Adams, A., de Silva, S. J. \& Razmara, S. (2013) Improving Skills Development in the Informal Sector: Strategies for SubSaharan Africa. Washington, DC: The World Bank.

Anifalaje, K. (2017). Implementation of the right to social security in Nigeria. African Human Journal, 413-435.

Ahmed, S. M. \& Ndyali L. (2018), Life Improvement on Retired Civil Servant in Tanzania: an Analysis of Social Security Policy in Tanzania. International Journal of New Technology and Research (IJNTR), 4(I), pp. 83-89.

Cameron, L. (2019), Social protection programs for women in developing countries. IZA: University of Melbourne. Daly, M. (2001), Care Work: The Quest for Security. Geneva: International Labour Office.

Dreze, J., Khera, R., \& Somanchi, A. (2021). Maternity Entitlements in India: Women's Rights Derailed. Ranchi: Ranchi University.

Fagan, C. \& Rubery, J. (2018), Advancing Gender Equality through European Employment Policy: The Impact of the UK's EU Membership and the Risks of Brexit. Social Policy \& Society, 17(2), pp. 297-317.

Halvorsen, E. \& Pedersen, A. W. (2019), Closing the gender gap in pensions: A Microsimulation analysis of the Norwegian NDC pension system. Journal of European Social Policy, 29(1), p. 3-12

Holmes, R. \& Scott, L. (2016), Extending social insurance to informal workers. Working Paper 438. London:

Holmes, R. Jones, N. \& Domingo, P. (2019), The politics of gender-responsive social protection. Working paper 568 ed. London: Overseas Development Institute. 
ILO. (2017), World Social Protection Report 2017-19: Universal social protection to achieve the Sustainable Development Goals, Geneva: International Labour Office ILO.

ILO. (2019), More than half the global population lacks health care and social security. [Online]Availableat:https://www.ilo.org/global/abouttheilo/newsroom/news/WCMS 675946/lang-en/index.htm[Accessed 20 June 2020].

Lewis, J. (2001), The Decline of the Male Breadwinner Model: The Implications for Work and Care. Social Politics, 8(2), pp. $152-169$.

Li, J., Feng, Y., \& Gizelis, I. (2008). China's New Social Security System in the Making: Problems and Prospects. Intl Journal of Public Administration, 5-23

Liebig, B. \& Gottschall, K. (2016), Gender Equality in Context:Policies and Practices in Switzerland. Opladen : Barbara Budrich Publishers.

Lokina, R. Nyoni, J. \& Kahyarara, G. (2016), Social Policy, Gender and Labour in Tanzania. Dar es Salaam: ESRF.

Masanyiwa, Z. S. Mosha, E. S. and Mamboya, S. F. (2020), Factors Influencing Participation of Informal Sector Workers in Formal Social Security Schemes in Dodoma City, Tanzania. Open Journal of Social Sciences, 8(6), pp. 1-14.

Matteazzi, E. Pailhé, A. \& Solaz, A. (2017), Part-time employment, the gender wage gap and the role of wage-setting institutions: Evidence from 11 European countries. European Journal of Industrial Relations, pp. 1 -21.

Mbashiru, K., \& Domasa, S. (2018, April 04). Pension Bill Signed into Complete Law. Retrieved from Daily News: https://www.dailynews.co.tz/news/pension-bill-signed-into-complete-law.aspx

Mhando, N. \& Kayuni, R. (2019), Challenges and coping strategies of employed mothers in a social security scheme in Tanzania. Tanzania Journal of Development Studies, $17(2)$.

Morse, J. (2010). Simultaneous and Sequential Qualitative Mixed Method Designs. Qualitative Inquiry, $483-491$.

Myamba, F., \& Kaniki, S. (2016). Social Protection: Safety Net or Vehicle for Transformation? Dar es Salaam: ESRF \& UNDP.

NBS. (2014), Tanzania Integrated Labour Force Survey. Dar Es Salaam: National Bureau of Statistics.

NSSF. (2018), The United Republic of Tanzania National Social Security Fund (NSSF). [Online]Availableat:https://www.nssf.or.tz/index.php/contactus [Accessed 2506 2020].

Piovani, C. \& Avsar, N. A. (2015), The Gender Impact of Social Protection Policies: A Critical Review of the Evidence, Review of the Political Economy. Routledge Taylor\&Francis Group, 27(3), pp. 410-441.

Plagerson, S. (2014), Do Social Protection Programmes That Impose Conditionalities on Women Fail to Confront Patriarchy as a Root Cause of Inequality?.[Online] Available at: https://socialprotection-humanrights.org/ expertcom/ do-social- protection- programmes- that- impose- conditionalities- on- women- fail-to-confrontpatriarchy-as-a-root-cause-of-inequality/[Accessed 21 June 2020].

Rwegoshora, H. M. (2016), Social Security Challenges in Tanzania: Transforming the Present -Protecting the Future. Dar es Salaam: Mkuki na Nyota.

Shen, K. Fengab, W. \& Caic, Y. (2016), The gender gap in pensions in Latin America, International Social Security Review, 70(2), pp. 76-84.

Sinem, B. (2019), EU's Gender Equality Dilemma: A Human Rights or a Market Economy Instrument?. Kadin/Woman 2000, 20(2), pp. 43-63.

Tessier, L., Plaza, S. M., Behrendt, C., \& Bonnet, F. (2013). Social Protection Floors and gender equality: A brief overview. Geneva: ILO.

Ulandssekretariatet. (2018), Tanzania and Zanzibar Labour Market Profile, Denmark: Danish Trade Union Development Agency Analytical Unit.

Ulrichs, M. (2016), Informality, women and social protection: Identifying barriers to provide effective coverage. Working Paper. London: ODI.

URT. (2014). National Panel Survey 2012 - 2013. Dar Es Salaam: NBS.

Publisher's note: Science Impact Publishers remain neutral with regard to jurisdictional claims in published maps and institutional affiliations.

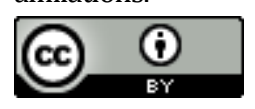

Open Access This article is licensed under a Creative Commons Attribution 4.0 International License, which permits use, sharing, adaptation, distribution and reproduction in any medium or format, as long as you give appropriate credit to the original author(s) and the source, provide a link to the Creative Commons license and indicate if changes were made. The images or other third-party material in this article are included in the article's Creative Commons license, unless indicated otherwise in a credit line to the material. If material is not included in the article's Creative Commons license and your intended use is not permitted by statutory regulation or exceeds the permitted use, you will need to obtain permission directly from the copyright holder. To view a copy of this license, visit https://creativecommons.org/licenses/by/4.0/.

(C) The Author(s) 2021 